\title{
Self Concept and Scholastic Competence of Secondary School Teachers in relation to some Personal Variables
}

\author{
Savita Mishra \\ Assistant Professor Harkamaya College of Education, Gangtok, Sikkim, India
}

\begin{abstract}
The self concept is an organized cognitive structure comprising a set of attitudes, beliefs and value that cut across all facets of experience and action, organizing together the variety of specific habits, abilities, outlooks, ideas and feelings that a person displays. Scholastic competence refers to the intellectual behavioral and manifestation activities that a teacher has developed from the early years of his schooling up to the attainment of degree of teaching. The objectives of this study was to find out significant difference if any in both self concept and scholastic competence of teachers in relation to gender, locale, teaching experience, educational qualification and academic stream variations. It was a descriptive study design of normative type. The population of this study consisted of secondary school teachers from Gangtok, East Sikkim. The sample included one hundred teachers selected on simple random sampling method. The tools used for the collection of data were Nayak's Teacher's Self Concept Scale (2004) and Samal's Scholastic Competence scale (2000). The findings of this study were that female, rural, more experienced, graduate and non science teachers have less self concept compared to urban, less experienced, science and post graduate teachers where as male, urban, graduate, non science, less experienced teachers have less scholastic competence compared to female, urban, post graduate, science and more experienced teachers.
\end{abstract}

Key Words: Self Concept, Scholastic Competence, Personal Variables

\section{Introduction}

The self concept is an organized cognitive structure comprising a set of attitudes, beliefs and value that cut across all facets of experience and action, organizing together the variety of specific habits, abilities, outlooks, ideas and feelings that a person displays. Self concept is a good predictor of our interpersonal behavior and adjustment skill, Rai (1983). According to Purkey (1988), self concept is the totally of a complex, organized, dynamic system of learned beliefs, attitudes and opinions that each person holds to be true about his/her personal existence. Self esteem is another way of viewing self concept. A person with high self esteem has a positive self concept while a person with low self esteem has a negative self concept. High self esteem is related to independence and open mindedness. As teachers are the builders of the nation and destiny makers, it becomes quiet obligatory on their part to develop high self concept and self esteem because the more the self concept, the more powerful he is in shaping the future. A substantial number of studies have been conducted on self concept of teachers as the criterion variable. The predicting variables to the criterion measures of self concept have been personal variables like age, gender, educational qualification, experience, academic stream, socio- economic status and intelligence and institutional variables like school environment, organizational climate, interpersonal relationship etc. Silberman (1969) has observed that teacher's self concept determines his perception which directly or indirectly affects his performing self. Teacher's having self concept was found to be more competent in teaching than their counterparts, i.e. there is a positive correlation between teacher's self concept and success in teaching. Thus self concept is the self estimation of an individual which is greatly influenced by factors like success and failure, social feedback as well as self identification.

Scholastic competence refers to the intellectual behavioral and manifestation activities that a teacher has developed from the early years of his schooling up to the attainment of degree of teaching. It is a summation of the intellectual pursuits one is having with the enrichment programmes that one experiences in his/her own life. It is the teachers who play a pivotal role in the educational system. Teacher competence in classroom procedures contributes more to teacher's abilities and also has a strong impact on the self concept of teachers. If the teachers have sound scholastic competence and can improve their communications and performance inside classroom, then they would be in a better position to communicate and understand their students as well as infer their own self concept. The teacher competence is manifested in the self concept of teachers and the self concept of teachers affects the classroom transactions and thus plays a vital role in shaping future citizens of our country. Samal (2000) conducted a study on teaching efficiency as a criterion of teacher's self concept, job satisfaction and scholastic competence and found out positive and significant relationship between the variables. Nayak (2004) conducted study on Mental Health and Adjustment of secondary school teachers influencing development of self concept in teachers over a random sample of 340 teachers. The findings of the study revealed sex, qualification, academic stream differences in self concept and a sound mental health was an 
important predictor of self concept. Chhetri (2007) conducted a study on self concept of prospective teachers of Sikkim in relation to sex, experience, qualification and place of habitation. It was observed that there existed sex, qualification, teaching experience and place of habitation difference in self concept of teachers.

\section{Rationale of the Study}

Basing upon the above, it is concluded that scholastic competence has been a predictor in selecting teachers for various institutions. As the public demand for accountability increases, schools of education are forced to identify the qualities of effective teachers and planned curricula to ensure that prospective teachers demonstrate those qualities prior to certification (Taylor, Middleton and Napier, 1990). This concern for teacher competence dated back to 1970, when the National Council for Accreditation of Teacher Education (NCATE) of America started to revise the accreditation standards. Hence, determining competence is both the concern of the accreditation party and the teacher education institute. With competence as an indicator in teacher accreditation and teacher development, there is a call for the refocusing of teacher education programmes. Taylor, Middleton and Napier (1990) have also advocated that the major thrust maximize the professional competence of teachers through development of positive self concept. The identification and determination of teacher competence are thus crucial in teacher education and development. Firstly teacher certification groups are using competence as an indicator. Secondly, teacher education institutes are planning their programmes which aim to maximize teacher competence. Thirdly, teacher educators are using teacher competence to reflect various stages of teacher development. A sincere attempt undertaken by the investigator to find out answers to the following questions; Are our teachers having self concept? Are there any differences in their self concept due to gender, experience, qualification, academic stream variations? Is scholastic competence necessary for developing positive self concept? Therefore, the investigator proposed to study the scholastic competence of teachers working in primary schools and its impact on their self concept in relation to gender, marital status, teaching experience, academic stream and educational qualification variations. In this context, the problem was stated as follows: "Self Concept and Scholastic Competence of Secondary School Teachers in relation to some Personal Variables."

\section{Objectives of the Study}

- To assess the self concept of teachers in relation to gender, locale, teaching experience, educational qualification and academic stream variations.

- To estimate the scholastic competence of teachers in relation to gender, locale, teaching experience, educational qualification and academic stream variations.

- To find out significant difference if any in both self concept and scholastic competence of teachers in relation to gender, locale, teaching experience, educational qualification and academic stream variations.

- To find out relationship between self concept and scholastic competence of teachers.

\section{Formulation of Hypotheses}

$\mathrm{Ho}_{1}$. There does not exist significant difference in the self concept of teachers in relation to gender variation.

$\mathrm{Ho}_{2}$. There does not exist significant difference in the self concept of teachers in relation to locale variation.

$\mathrm{Ho}_{3}$. There does not exist significant difference in the self concept of teachers in relation to teaching experience variation.

$\mathrm{Ho}_{4}$. There does not exist significant difference in the self concept of teachers in relation to educational qualification variation.

$\mathrm{Ho}_{5}$. There does not exist significant difference in the self concept of teachers in relation to academic stream variation.

$\mathrm{Ho}_{6}$. There does not exist significant difference in the scholastic competence of teachers in relation to gender variation.

$\mathrm{Ho}_{7}$. There does not exist significant difference in the scholastic competence of teachers in relation to locale variation.

$\mathrm{Ho}_{8}$. There does not exist significant difference in the scholastic competence of teachers in relation to teaching experience variation.

$\mathrm{Ho}_{9}$. There does not exist significant difference in the scholastic competence of teachers in relation to educational qualification variation.

$\mathrm{Ho}_{10}$. There does not exist significant difference in the scholastic competence of teachers in relation to academic stream variation.

$\mathrm{Ho}_{11}$. There does not exist significant relationship in the self concept and scholastic competence of teachers. 
Operational Definitions of the terms used themselves."

Self Concept: It refers to "the composite of ideas, feelings and attitudes people have about

Scholastic Competence: It refers to "the outcomes desired from teaching, which ranges from increased classroom average scores on standardized achievement tests to the development of pupils' social skills, length of time in teaching, the conception of the teacher's role, the context for teaching such as school characteristics and the geographic location."

Secondary School Teachers: Teachers who teach students from classes IX and X. academic stream.

Personal Variables: It refers to gender, locale, teaching experience, educational qualification and

\section{Scope and Delimitation of the Study}

The scope of the study was to assess the self concept and scholastic competence of 100 secondary school teachers selected on simple random basis from Gangtok, East Sikkim in relation to gender, locale, teaching experience, educational qualification and academic stream variations.

Method of study: The Design: It was a descriptive study design of normative type.

Sample: The population of this study consisted of secondary school teachers from Gangtok, East Sikkim. The sample included one hundred teachers selected on simple random sampling method.

Tools Used: The tools used for the collection of data were Nayak's Teacher's Self Concept Scale (2004) and Samal's Scholastic Competence Scale (2000).

\section{Categorization of teachers on their Self Concept}

\section{Results and Discussions}

One of the objectives of the study was to find out if there exists any gender difference in the self concept values of teachers. The t-test (test of significance) between the means was calculated and it was 1.77 for 98 degree of freedom. But the table value of $t$ was 2.63 for the same degree of freedom. Therefore, the t-ratio being lower than the table value was considered to be insignificant. Hence, the null hypothesis was retained. This showed that male teachers are not different from female teachers in their self concept value. In this connection Studies of Nayak (2004) and Samal (2000) might be referred to where female teachers were found to have better self concept than male teachers. Therefore, the investigator desired to conclude that the findings of the study were appropriate.

Table 1

Test of significance of difference between the means of the contrasts on Self Concept of teachers

\begin{tabular}{|c|c|c|c|c|c|c|c|}
\hline Contrast & $\mathbf{N}$ & Mean & SD & $\mathbf{S}_{\mathrm{ED}}$ & Df & 't' & $\begin{array}{l}\text { Test of } \\
\text { Significance }\end{array}$ \\
\hline $\begin{array}{l}\text { Male } \\
\text { Vs } \\
\text { Female }\end{array}$ & $\begin{array}{l}50 \\
50\end{array}$ & $\begin{array}{l}135.18 \\
131.88\end{array}$ & $\begin{array}{l}6.23 \\
11.57\end{array}$ & 1.86 & 98 & 1.77 & Not Significant \\
\hline $\begin{array}{l}\text { Rural } \\
\text { Vs } \\
\text { Urban } \\
\end{array}$ & $\begin{array}{l}51 \\
49 \\
\end{array}$ & $\begin{array}{r}131.73 \\
133.71 \\
\end{array}$ & $\begin{array}{l}19.04 \\
9.72 \\
\end{array}$ & 3.01 & 98 & 0.66 & Not Significant \\
\hline $\begin{array}{l}\text { More Experience } \\
\text { Vs } \\
\text { Less Experience }\end{array}$ & $\begin{array}{l}58 \\
42 \\
\end{array}$ & $\begin{array}{l}98.28 \\
131.05 \\
\end{array}$ & $\begin{array}{l}32.30 \\
10.63 \\
\end{array}$ & 4.60 & 98 & 7.12 & $\mathrm{P}<0.01$ \\
\hline $\begin{array}{l}\text { Post graduate } \\
\text { Vs } \\
\text { Graduate }\end{array}$ & $\begin{array}{l}61 \\
39\end{array}$ & $\begin{array}{r}133.89 \\
133.74\end{array}$ & $\begin{array}{l}8.35 \\
10.54\end{array}$ & 2 & 98 & 0.08 & Not Significant \\
\hline $\begin{array}{l}\text { Non Science } \\
\text { Vs } \\
\text { Science }\end{array}$ & $\begin{array}{l}67 \\
33 \\
\end{array}$ & $\begin{array}{r}133.30 \\
134.91 \\
\end{array}$ & $\begin{array}{l}9.19 \\
9.32 \\
\end{array}$ & 1.97 & 98 & 0.82 & Not Significant \\
\hline Total & 100 & 133.53 & 9.45 & & & & \\
\hline
\end{tabular}

Detailed analysis of the table 1 revealed that the mean of the Self Concept was 133.53. The Standard Deviation value had been estimated to be 9.45. It was further observed that the mean scores of male, urban, post Graduate, graduate and Science teachers lied above the mean value of the total sample. This indicated that female, rural, less experienced, and non- science teachers have self concept scores below the normal average of the total sample.

The locale wise difference in the self concept value of teachers was calculated. The t-test between the means was calculated and it was 0.66 for 98 degrees of freedom. But the table value of $t$ was 2.63 for the same degree 
of freedom. Therefore, the t-ratio being lower than the table value was considered to be insignificant. Hence, the null hypothesis was retained. This showed that rural teachers were not different from urban teachers in their self concept values. Therefore, the investigator desired to conclude that the findings of the study were appropriate. The teaching experience wise difference in the Self Concept value of teachers was calculated. The t-test between the means was calculated and it was 7.12 for 98 degrees of freedom. But the table value of $t$ was 2.63 for the same degree of freedom. Therefore, the t-ratio being lower than the table value was considered to be significant. Hence, the null hypothesis was rejected. This showed that more experienced teachers are different from less experienced teachers in their self concept values. The studies of Lee (1992) and Mani and Gonsalves (1997) might be referred were experienced teachers exhibited better self concept than their counterparts. Hence, the investigator desired to conclude that the findings of the study were appropriate.

The educational qualification wise difference in the self concept value of teachers was calculated. The t-test between the means was calculated and it was 0.08 for 98 degrees of freedom. But the table value of $t$ was 2.63 for the same degree of freedom. Therefore, the t-ratio being lower than the table value was considered to be insignificant. Hence, the null hypothesis was retained. This showed that post graduate teachers are not different from graduate teachers in their self concept values. The studied done by Rai (1983) revealed this fact that post graduate teachers had significantly better self concept than graduate teachers. Therefore, it was concluded that the findings of the study were appropriate.

The Academic Stream wise difference in the Self Concept value of teachers was calculated. The t-test between the means was calculated and it was 0.82 for 98 degrees of freedom. But the table value of $t$ was 2.63 for the same degree of freedom. Therefore, the t-ratio being lower than the table value was considered to be insignificant. Hence, the null hypothesis was retained. This showed that non-science teachers were not different from science teachers in their Self Concept values. Therefore, the investigator desired to conclude that the findings of the study were appropriate.

\section{Categorization of teachers on their Scholastic Competence}

Table 2

Test of significance of difference between the means of the contrasts on Scholastic Competence of teachers

\begin{tabular}{|c|c|c|c|c|c|c|c|}
\hline Contrast & $\mathbf{N}$ & Mean & SD & $\mathbf{S}_{\mathrm{ED}}$ & Df & ' $t$ ' & $\begin{array}{l}\text { Test of } \\
\text { Significance }\end{array}$ \\
\hline $\begin{array}{l}\text { Male } \\
\text { Vs } \\
\text { Female }\end{array}$ & $\begin{array}{l}50 \\
50\end{array}$ & $\begin{array}{l}26.60 \\
30.30\end{array}$ & $\begin{array}{l}11.19 \\
12.85\end{array}$ & 2.41 & 98 & 1.54 & Not Significant \\
\hline $\begin{array}{l}\text { Rural } \\
\text { Vs } \\
\text { Urban }\end{array}$ & $\begin{array}{l}51 \\
49\end{array}$ & $\begin{array}{l}24.86 \\
32.18\end{array}$ & $\begin{array}{l}10.27 \\
12.88\end{array}$ & 2.34 & 98 & 1.12 & Not Significant \\
\hline $\begin{array}{l}\text { More Experience } \\
\text { Vs } \\
\text { Less Experience }\end{array}$ & $\begin{array}{l}58 \\
42\end{array}$ & $\begin{array}{l}25.53 \\
18.90\end{array}$ & $\begin{array}{l}11.98 \\
4.82\end{array}$ & 1.74 & 98 & 3.81 & Significant \\
\hline $\begin{array}{l}\text { Post graduate } \\
\text { Vs } \\
\text { Graduate }\end{array}$ & $\begin{array}{l}61 \\
39\end{array}$ & $\begin{array}{l}30.82 \\
24.74\end{array}$ & $\begin{array}{l}11.30 \\
12.54\end{array}$ & 2.47 & 98 & 2.46 & Not Significant \\
\hline $\begin{array}{l}\text { Non Science } \\
\text { Vs } \\
\text { Science }\end{array}$ & $\begin{array}{l}67 \\
33\end{array}$ & $\begin{array}{l}26.72 \\
31.97\end{array}$ & $\begin{array}{l}10.77 \\
13.99\end{array}$ & 2.77 & 98 & 1.90 & Not Significant \\
\hline Total & 100 & 28.45 & 11.37 & & & & \\
\hline
\end{tabular}

Detailed analyses of the table 2 revealed that the mean of the scholastic competence was 28.45 . The Standard Deviation value had been estimated to be 11.37. It was further observed that the mean scores of female, urban, post graduate and science teacher lie above the mean value of the total sample. This indicated that male, rural, graduate, non- science, more experienced teachers have scholastic competence scores below the normal average of the total sample. The gender wise difference on Scholastic Competence values of teachers was calculated. The ' $t$ ' test between the means was calculated and it was 1.54 for 98 degrees of freedom. But table value of $t$ was 2.63 for the same degree of freedom. Therefore, the t-ratio being lower than the table value was considered to be insignificant. Hence the null hypothesis was retained. This showed that male teachers were not different from female teachers in scholastic Competence values but female teachers having higher mean value from the male had been considered to be having more scholastic competence values compared of the males. In this connection, studies of Samal (2000) might be referred where female teachers were found to have better scholastic competence than male teachers. Therefore, the investigator desired to conclude that the findings of the study were appropriate. 
The locale wise difference in the Scholastic Competence value of teachers was calculated. The t-test between the means was calculated and it was 1.12 for 98 degrees of freedom. But the table value of $t$ was 2.63 for the same degree of freedom. Therefore, the t-ratio being lower than the table value was considered to be insignificant. Hence, the null hypothesis was retained. This showed that rural teachers were not different from urban teachers in their Scholastic Competence values. Therefore, the investigator desired to conclude that the findings of the study were appropriate.

The teaching experience wise difference in the Scholastic Competence value of teachers was calculated. The ttest between the means was calculated and it was 3.81 for 98 degrees of freedom. But the table value of $t$ was 2.63 for the same degree of freedom. Therefore, the t-ratio being lower than the table value was considered to be significant. Hence, the null hypothesis was rejected. This showed that more experienced teachers were different from less experienced teachers in their Scholastic Competence values. Therefore, the investigator desired to conclude that the findings of the study were appropriate.

The educational qualification wise difference in the Scholastic Competence value of teachers was calculated. The t-test between the means was calculated and it was 2.46 for 98 degrees of freedom. But the table value of $t$ was 2.63 for the same degree of freedom. Therefore, the t-ratio being lower than the table value was considered to be insignificant. Hence, the null hypothesis was retained. This showed that post graduate teachers were not different from graduate teachers in their Scholastic Competence values. Thus, the investigator desired to conclude that the findings of the study were appropriate.

The Academic Stream wise difference in the Scholastic Competence value of teachers was calculated. The t-test between the means was calculated and it was 0.82 for 98 degrees of freedom. But the table value of $t$ was 2.63 for the same degree of freedom. Therefore, the t-ratio being lower than the table value was considered to be insignificant. Hence, the null hypothesis was retained. This showed that non-science teachers were not different from science teachers in their Scholastic Competence values. Therefore, the investigator desired to conclude that the findings of the study were appropriate.

\section{Relationship Study between Scholastic Competence and Self Concept of teachers.}

Relationship study was established through Product Moment Correlation total wise and the Coefficient of Correlation was found to be -0.02 , i.e., Self Concept and Scholastic Competence was negatively correlated. So it was observed that the relationship between Self Concept and Scholastic Competence in total was insignificant. Therefore, the null hypothesis that there does not exist significant relationship in Self Concept and Scholastic Competence could be rejected which showed that Self Concept is negatively related to Scholastic Competence.

\section{Findings of the study}

- Female, rural, more experienced, graduate and non science teachers have less Self Concept compared to urban, less experienced, science and post graduate teachers.

- Male, urban, graduate, non science, less experienced teachers have less Scholastic Competence compared to female, urban, post graduate, science and more experienced teachers.

- There is no relationship between the male and female teachers in case of Self Concept.

- There is no relationship between the male and female teachers in case of Scholastic Competence.

- There is no relationship between rural and urban teachers in case of Self Concept.

- There is no relationship between rural and urban teachers in case of Scholastic Competence.

- More experienced teachers have less Self Concept than less experienced teachers.

- More experienced teachers have more Scholastic Competence than less experienced teachers.

- There is no relationship between post graduate and graduate teachers in case of Self Concept.

- There is no relationship between post graduate and graduate teachers in case of Scholastic Competence.

- There is no relationship between science and non science teachers in case of Self Concept.

- There is no relationship between science and non science teachers in case of Scholastic Competence.

- Self Concept and Scholastic Competence of teachers is negatively correlated.

\section{Recommendations}

- Building a healthy school community relationship for smooth transaction of business of the school.

- Encouraging the development of the confidence in teachers.

- Assuring better service condition by enforcement of law.

- Strengthening the principle of recruitment to teaching professions.

- Emphasizing on better school organizational climate for better co-operation.

- Respecting persons and feelings of teachers. 
- Equipping schools with all modern and information technology based materials.

- Maintaining teachers' profile for better and systematic understanding of each individual teacher.

- For the development of better self concept.

\section{References}

[1]. Chhetri, S. (2007). Self Concept of Prospective teachers of Sikkim in relation to Gender, Experience, Qualification and Place of Habitation. Unpublished Dissertation in Education, University of North Bengal.

[2]. Lee, C.1. (1992). The relationship between Home Economics teachers' Self esteem and their classroom interaction. Dissertation Abstract International. Vol-53.

[3]. Mani, G. and Gonsalves, C.A. (1977). A study of self Concept of student teachers in relation to their performance in practical teaching. Stella Matutina College of Education, Madras.

[4]. Nayak, N. (2004). Mental Health and Adjustment of Secondary School Teacher influencing development of Self Concept in teacher. Unpublished Ph.D Dissertation in Education, Utkal University.

[5]. Purkey, W. (1988). An overview of Self Concept Theory for Counseling. ERIC Clearing House ERIC/CAPS Digest: ED. 304630 www.Document URL.http.edu.

[6]. Rai, G. (1983). A Study of Self Concept of the prospective teachers. Unpublished Doctoral Dissertation in Education, BHU.

[7]. Samal, A. (2000). Teaching Efficiency as a function of Self Concept, job Satisfaction and Scholastic Competence. Unpublished dissertation in education, Utkal University.

[8]. Silberman, M. (1996). Behavior Expression of Teachers Attitudes Elementary School Students. Journal of Educational Psychology, Vol. 60, pp. 402-407. 